\title{
Oocyte-Specific Expression of Growth/Differentiation Factor-9
}

\author{
Sharon A. McGrath, Aurora F. Esquela, and Se-Jin Lee \\ Department of Molecular Biology and Genetics \\ Johns Hopkins University School of Medicine \\ Baltimore, Maryland 21205
}

Growth/differentiation factor-9 (GDF-9) is a previously described member of the transforming growth factor- $\beta$ superfamily expressed specifically in the ovary in adult mice. Using in situ hybridization methods, we have localized the expression of GDF-9 messenger RNA (mRNA) exclusively to oocytes. GDF-9 mRNA was detected in oocytes at all stages of follicular development, except in primordial follicles, in both neonatal and adult ovaries. GDF-9 mRNA continued to be expressed in oocytes after ovulation, but disappeared by 1.5 days after fertilization. Based on Westem analysis of ovarian extracts using antibodies raised against recombinant GDF-9 protein, GDF-9 mRNA expressed by oocytes appears to be translated. A human homolog of GDF-9 was isolated from a complementary DNA ibrary prepared from adult ovary mRNA. The predicted human protein is $\mathbf{9 0 \%}$ identical to murine GDF-9 in the mature portion of the molecule. These results are significant because no other growth factor-like molecules have been shown to be expressed specifically by oocytes and, together with results of previous studies, suggest that ovarian development and function are regulated by factors produced by both oocytes and support cells of the ovary. (Molecular Endocrinology 9: 131-136, 1995)

\section{INTRODUCTION}

A large number of growth and differentiation factors believed to play essential roles in regulating development have been found to be structurally related to transforming growth factor- $\beta$ (TGF $\beta$ ). Among the known members of the TGF $\beta$ superfamily, for example, are decapentaplegic, which is necessary for proper dorsal/ventral axis formation and development of the imaginal disks in Drosophila (1); Vg-1 $(2,3)$ and the activins (4-7), which can induce mesoderm formation in Xenopus animal caps; nodal, which appears to be essential for mesoderm formation in mice (8); dorsalin-1, which can regulate neural crest cell migration and motor neuron differentiation in chick neural

0888-8809/95/303.00/0

Molecular Endocrinology

Copyright 01995 by the Endocrine Society plate explant cultures (9); Mullerian inhibiting substance, which is essential for normal male sex development in mammals (10-12); the bone morphogenetic proteins, which are capable of inducing de novo cartilage and bone formation and appear to be essential for normal skeletal development during mammalian embryogenesis (13-18); and glial cell-derived neurotrophic factor, which can promote the survival of midbrain dopaminergic neurons (19).

The biologically active forms of these secreted factors are believed to be generated by proteolytic cleavage from a larger precursor protein. For the most part, it is only in the mature carboxy-terminal fragments that the different family members are related with respect to their amino acid sequence. To identify additional factors that may play important roles in regulating cell differentiation processes during development, we have isolated novel TGF $\beta$ family members using degenerate oligonucleotides corresponding to conserved regions among the known family members. We previously reported the identification of a distantly related family member [designated growth/differentiation factor-9 (GDF-9)] expressed specifically in the ovary in adult mice (20). Here we report that GDF-9 is expressed exclusively by oocytes. The oocyte specificity of GDF- 9 is unique among known growth factorlike molecules and suggests that oocyte development in mammals is regulated by a complex interplay of factors elaborated by both oocytes and support cells.

\section{RESULTS}

Expression of GDF-9 Messenger RNA (mRNA) in Oocytes

By Northern analysis, we previously detected GDF-9 mRNA expression only in the ovary among a large number of adult tissues surveyed (20). To localize the expression of GDF-9 within the ovary, we carried out in situ hybridization experiments using GDF-9 RNA probes on sections of ovaries prepared from randomly cycling adult mice. Figure 1 shows representative fields of adjacent sections hybridized with either antisense or sense RNA probes transcribed in vitro from plasmids containing portions of the murine GDF-9 complementary DNA (cDNA) sequence. The antisense 

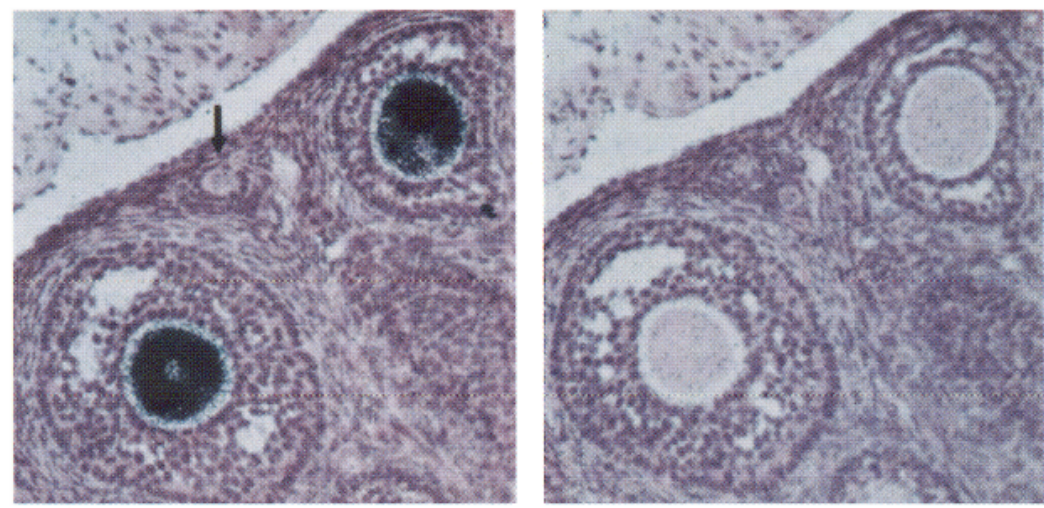

Fig. 1. Localization of GDF-9 mRNA in Adult Ovary Sections

Adjacent sections of ovaries prepared from randomly cycling mice were hybridized with either antisense (left panel) or sense (right panel) GDF-9 riboprobes, dipped in photographic emulsion, developed, and stained with hematoxylin and eosin. A primordial follicle negative for GDF-9 expression is noted by an arrow.

probe detected GDF-9 mRNA present exclusively in oocytes. No hybridization was seen with a control sense probe, and no hybridization was detected in any other ovarian cell type, including thecal and granulosa cells. GDF-9 mRNA was detected in oocytes at all stages of follicular development, except for those present in primordial follicles. Although the intensity of hybridization varied somewhat among different oocytes, there was no obvious correlation between the level of GDF-9 mRNA expression and the stage of follicular development.

\section{Expression of GDF-9 mRNA during Oocyte Development}

To further characterize the expression of GDF-9 in oocytes, we carried out in situ hybridization experiments on sections of ovaries isolated at various developmental stages. The earliest stage of ovarian development that we examined were ovaries taken from day 17.5 postcoital (pc) embryos. At this stage, the oocytes were small and present in primordial follicles, which were characterized by a single layer of squamous follicular cells. By in situ hybridization, we were unable to detect the expression of GDF-9 mRNA in these fetal oocytes (data not shown).

In contrast, GDF-9 mRNA was clearly present in postnatal oocytes. By postnatal day 4 , many of the follicles were characterized by the presence of an enlarged oocyte surrounded by more cuboidal or columnar follicular cells. As shown in Fig. 2A, oocytes present in these primary follicles all showed GDF-9 mRNA expression, whereas oocytes present in primordial follicles were all negative. By postnatal day 8 , intense hybridization was seen in oocytes in primary follicles (Fig. 2B).

We also examined the expression of GDF-9 mRNA in oocytes after ovulation. As shown in Fig. 3A, GDF-9 mRNA continued to be expressed by oocytes that had been released into the oviduct. However, GDF-9 mRNA expression appeared to be lost rapidly after
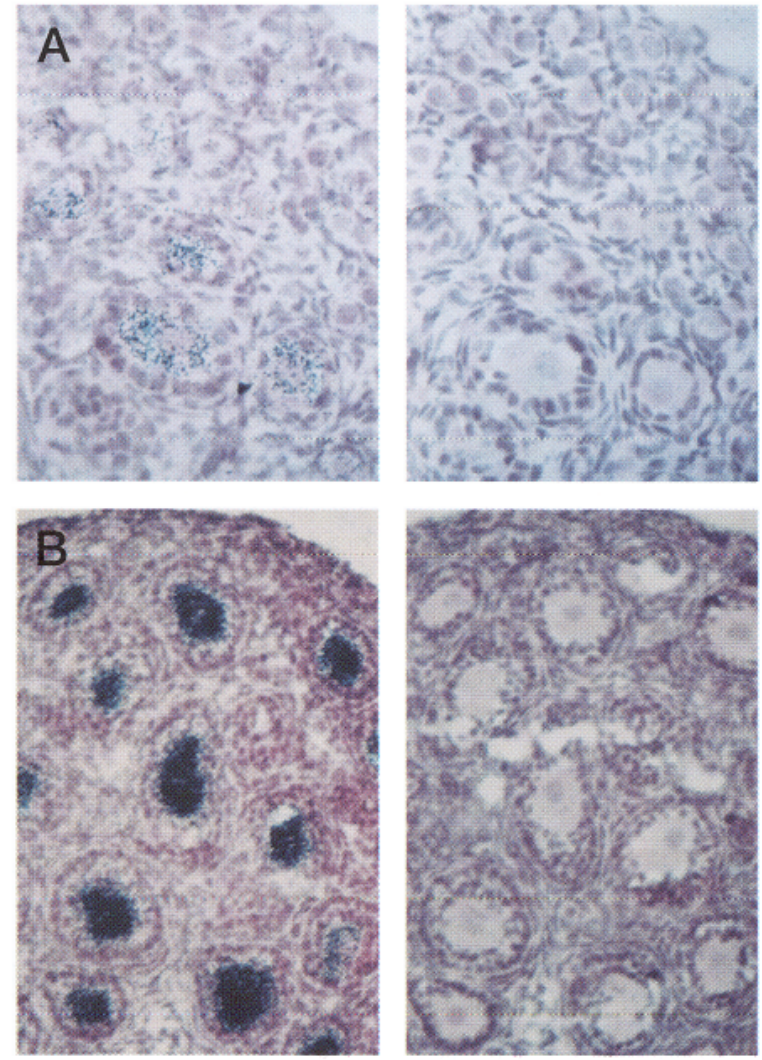

Fig. 2. Expression of GDF-9 in Neonatal Ovaries

Sections of ovaries isolated from postnatal day 4 (A) or postnatal day 8 (B) mice were hybridized with either antisense (left panels) or sense (right panels) GDF-9 riboprobes and analyzed as described in Fig. 1.

fertilization. By day $0.5 \mathrm{pc}$, GDF-9 mRNA was detected in some, but not all, embryos (Fig. 3B), and by day $1.5 \mathrm{pc}$, GDF-9 mRNA expression was no longer detected (data not shown). In day 0.5 pc embryos in which GDF-9 mRNA was detected, the intensity of 

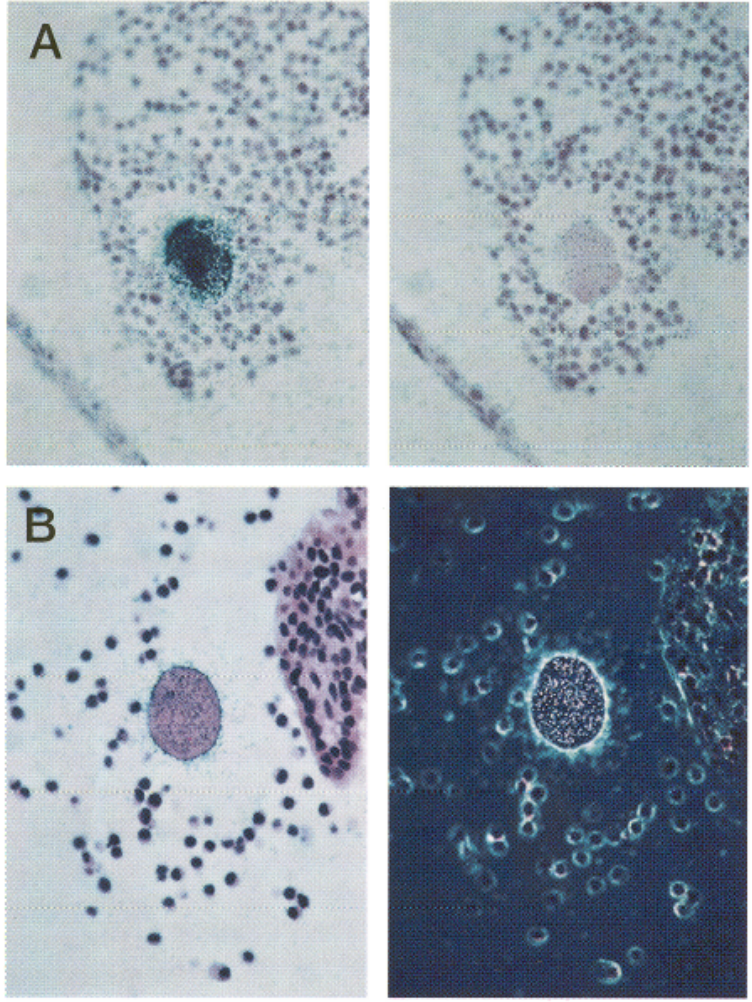

Fig. 3. Expression of GDF-9 in Unfertilized and Fertilized Oocytes

A, Sections of oviducts isolated from unmated mice were hybridized with either antisense (left panel) or sense (right panel) GDF-9 riboprobes and analyzed as described in Fig. 1. $\mathrm{B}$, Sections of oviducts isolated from day $0.5 \mathrm{pc}$ females were hybridized with antisense GDF- 9 riboprobes and, after autoradiography, photographed under either brightfield (left panel) or darkfield (right panel) illumination.

hybridization appeared to be highest at the periphery of the cell (Fig. 3B). Although only a single embryo is shown, the ring-like pattern of hybridization was also seen in two other embryos at this stage (data not shown). This pattern of hybridization was less pronounced in unfertilized oocytes and was never seen in oocytes before ovulation or with a control sense probe in oocytes or embryos at any stage of development.

\section{Detection of GDF-9 Protein in Adult Ovary}

To determine whether GDF-9 mRNA expressed in the ovary is translated into protein, we raised antisera against GDF-9 protein. To avoid possible cross-reactivity of these antibodies with related proteins, we prepared antibodies directed against the pro region of GDF-9, which showed no obvious sequence homology to the pro regions of other known family members. Specifically, we expressed the portion of GDF-9 spanning amino acids 30-295 in bacteria and immunized rabbits with gel-purified protein. The presence of GDF9-reactive antibodies in the serum of these rabbits was verified by Western analysis of bacterially expressed protein fragments (data not shown).

As shown in Fig. 4, Western analysis using these anti-GDF-9 antibodies detected a protein with an approximate mol wt of 37,000 in extracts prepared from adult ovary. This band was not seen in a variety of other tissues examined. Based on the cDNA sequence (20), the full-length GDF-9 protein was predicted to have a mol wt of approximately 49,600 . After proteolytic cleavage following the signal sequence and at the putative processing site at amino acids 303-306, the pro region was predicted to have a mol wt of approximately 31,000 . We presume that the difference between the apparent mol wt and the predicted mol wt represents the presence of posttranslational modifications, such as glycosylation at one or more of the three potential $\mathrm{N}$-glycosylation sites present in the pro region.

\section{Isolation of Human GDF-9}

Because GDF- 9 was originally identified in mice, which are multiparous, we sought to determine whether GDF-9 homologs are also present in uniparous species. In particular, we prepared a cDNA library from RNA isolated from human ovaries and screened this library using a murine GDF-9 cDNA probe. From 7.5 million primary recombinant phages screened, we isolated 12 hybridizing clones and determined the entire nucleotide sequence of the longest insert. The 1774-basepair sequence contained a single long open reading frame encoding a protein highly related to murine GDF-9 (Fig. 5). Like the predicted murine GDF-9 amino acid sequence, the predicted human sequence contained a hydrophobic stretch of amino acids at the $\mathrm{N}$-terminus suggestive of a signal sequence for secretion, a putative RXXR cleavage site 135 amino acids from the C-terminus, and a C-terminal region that showed significant homology to other members of the TGF $\beta$ superfamily. As is characteristic

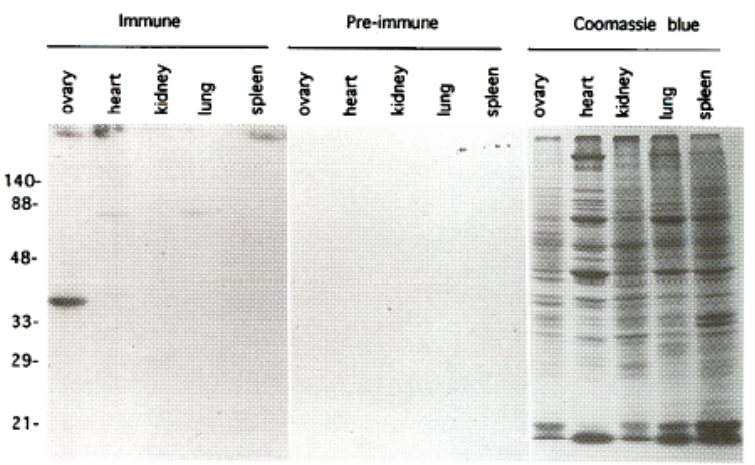

Fig. 4. Expression of GDF-9 Protein

Extracts prepared from various adult tissues were electrophoresed on SDS-polyacrylamide gels and either stained with Coomassie blue or transferred to nitrocellulose and probed with anti-GDF-9 (immune) or preimmune sera. Numbers at the left indicate the mobilities of the mol wt standards. 


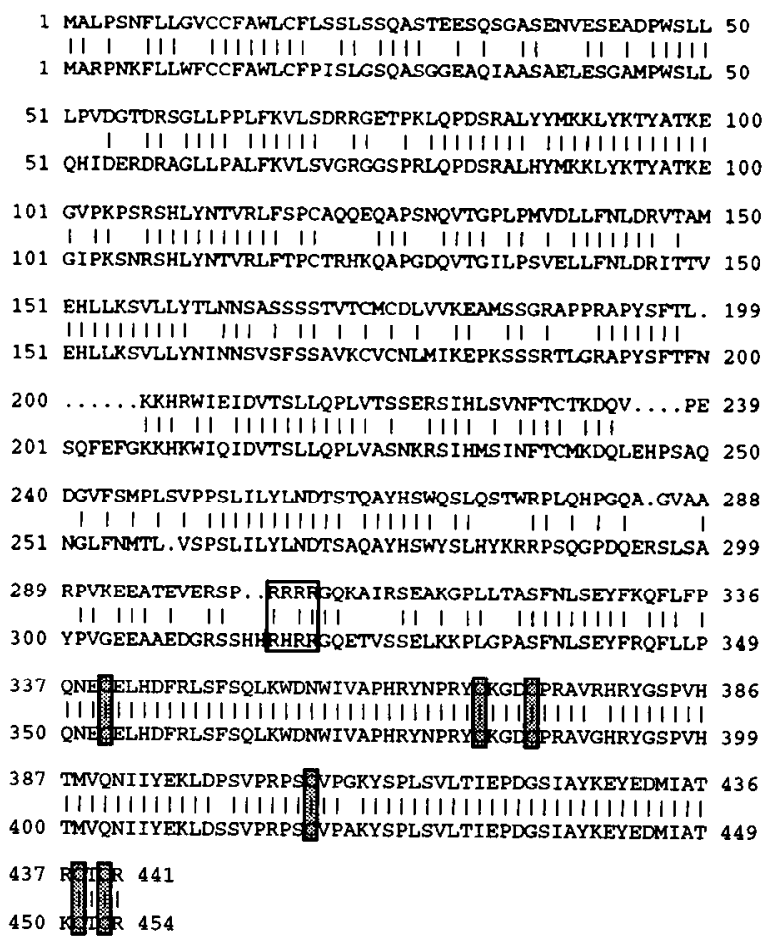

Fig. 5. Comparison of the Predicted Amino Acid Sequences of Murine (Top Lines) and Human (Bottom Lines) GDF-9

Numbers indicate amino acid positions relative to the $\mathrm{N}$ termini. The predicted proteolytic processing sites are boxed. The conserved cysteine residues in the $\mathrm{C}$-terminal regions are shaded.

of other members of the TGF $\beta$ superfamily, the homology between murine and human GDF-9 was significantly higher in the mature C-terminal portion ( $\sim 90 \%$ amino acid sequence identity) than in the pro region ( $60 \%$ amino acid sequence identity) of the molecule.

\section{DISCUSSION}

GDF-9 was originally identified by polymerase chain reaction using degenerate oligonucleotides corresponding to conserved regions among known members of the TGF $\beta$ superfamily (20). Although GDF- 9 is clearly a new member of the TGF $\beta$ superfamily, GDF- 9 is only distantly related to other family members. By Northern analysis, GDF-9 mRNA was detected only in the ovary among a large number of adult tissues surveyed. In this report, we describe the localization of GDF-9 mRNA exclusively to oocytes in both neonatal and adult ovaries. The onset of GDF- 9 expression during ovarian development appears to coincide with the formation of primary follicles. GDF-9 mRNA continues to be expressed by oocytes throughout follicular development as well as after ovulation, but disappears by day 1.5 after fertilization.

Other growth factor-like molecules are known to be expressed in the ovary and are believed to influence ovarian development and function (for review, see Ref. 21). These include members of the TGF $\beta$ superfamily, such as Mullerian inhibiting substance (12, 22-24), Vgr-1 (25), inhibin and activin subunits, and the TGF $\beta$ s themselves (21), as well as members of other growth factor families, such as steel factor (26), epidermal growth factor, TGF $\alpha$, tumor necrosis factor- $\alpha$, insulin, insulin-like growth factors, basic fibroblast growth factor, and interleukin-1 (21). However, the expression pattern of GDF- 9 is unique compared with those of other growth factor-like molecules in its apparent specificity for the ovary and, in particular, for the oocyte. In fact, to our knowledge, Vgr-1 is the only other growth factor-like molecule that has been demonstrated to be expressed by oocytes, and unlike GDF-9, Vgr-1 is also expressed by other cell types within the ovary as well as in other tissues $(25,27)$. The oocyte specificity of GDF-9 suggests that oocyte maturation involves not only growth factors produced by support cells of the ovary, but also factors secreted by the oocyte itself.

Although the biological function of GDF-9 is not yet known, the expression pattern of GDF-9 suggests several possible regulatory roles for GDF-9. For example, GDF-9 may play an autocrine role in regulating the maturation of the oocyte. In this regard, at least two unidentified factors have been detected in follicular fluid that can maintain oocytes in meiotic arrest $(28$, 29), although the apparent mol wt of these factors do not correspond to that predicted for GDF-9. Alternatively, GDF-9 may play a paracrine role. One possibility, for example, is that GDF-9 may play a role in regulating the proliferation and/or differentiation of granulosa cells. Although there have been many hypotheses put forth regarding the role of oocytederived factors in regulating follicle formation, such factors have not yet been identified or characterized. Another potential paracrine role for GDF- 9 might be in regulating sperm-egg interactions. In sea urchins, it is known, for example, that oocytes produce factors that are chemotactic for sperm (30), and there are some reports that such factors may also exist in mammals $(31,32)$. Finally, it is possible that GDF-9 may be involved in regulating early embryonic development. We do not believe, however, that GDF-9 is solely a stored maternal mRNA to be used during early embryogenesis, because we have been able to detect the presence of GDF-9 protein in adult ovary. Nevertheless, the relatively long window of GDF-9 expression during oocyte development suggests that perhaps GDF-9 may play multiple regulatory roles.

Whatever role(s) GDF-9 may play in regulating ovarian development and function, the function of GDF-9 does not appear to be unique to animals with multiple ovulatory potential. In particular, we have identified a human gene that encodes a protein that is $90 \%$ identical to murine GDF-9 in the predicted mature portion of the molecule. The high degree of sequence conservation between murine and human GDF-9 suggests 
that GDF-9 carries out an important function in both multiparous and uniparous species.

\section{MATERIALS AND METHODS}

\section{In Situ Hybridizations}

For RNA localization studies, all tissue samples were taken from CD-1 mice (Charles River, Wilmington, MA). All animal studies were conducted in accord with the principles and procedures outlined in the Guidelines for Care and Use of Experimental Animals. Timed pregnancies were obtained from random matings, and the beginning of day 0 was considered to be the midpoint of the dark cycle preceding the morning on which the vaginal plug was noted. Ovaries or oviducts were fixed in $4 \%$ paraformaldehyde, embedded in paraffin, and sectioned. In situ hybridizations were carried out as previously described (33). ${ }^{35}$ S-Labeled riboprobes were transcribed from GDF-9 cDNA subclones representing nucleotides 1-903 or 901-1644 (20). The two antisense (or sense) probes from these subclones were mixed together for hybridization. Autoradiography was carried out using NTB-3 photographic emulsion (Eastman Kodak, Rochester, NY). Exposure times ranged from 7-10 days.

\section{Detection of GDF-9 Protein}

For antibody production, the GDF-9 coding sequence spanning amino acids 30-295 was cloned into the pET3 expression vector (kindly provided by F. W. Studier), and the resulting plasmid was transformed into BL21 (DE3) cells. Cells were induced with isopropyl $\beta$-D-thiogalactoside, and GDF-9 protein was gel purified from total cell extracts. All immunization procedures were carried out by Spring Valley Lab (Sykesville, MD). Tissue extracts were prepared by homogenization in sample buffer. Western analysis was carried out as previously described (34), except that $5 \%$ nonfat dried milk was used as the blocking agent. Antisera were used at a dilution of $1: 1000$.

\section{Isolation of Human GDF-9}

Human ovaries were obtained from the International Institute for the Advancement of Medicine (Exton, PA). RNA isolation, CDNA library construction, and isolation and characterization of cDNA clones were carried out as described previously (35).

\section{Acknowledgments}

We thank Thanh Huynh, Alexandra McPherron, and Teresa Zimmers for helpful discussions, and Christine Moss for assistance in preparing the manuscript.

Received April 21, 1994. Revision received September 27, 1994. Accepted September 29, 1994.

Address requests for reprints to: Dr. Se-Jin Lee, Department of Molecular Biology and Genetics, Johns Hopkins University School of Medicine, 725 North Wolfe Street, Baltimore, Maryland 21205.

This work was supported by a Parker B. Francis Fellowship and a Bauemschmidt Fellowship (to S.A.M.) and by grants from the Edward Mallinckrodt, Jr., Foundation, the NIH, and the American Cancer Society (to S.-J.L).

\footnotetext{
family. Cell 71:399-410

\section{REFERENCES}

1. Padgett RW, St Johnston RD, Gelbart WM 1987 A transcript from a Drosophila pattern gene predicts a protein homologous to the transforming growth factor- $\beta$ family. Nature 325:81-84

2. Weeks DL, Melton DA 1987 A matemal mRNA localized to the vegetal hemisphere in Xenopus eggs codes for a growth factor related to TGF- $\beta$. Cell 51:861-867

3. Thomsen GH, Melton DA 1993 Processed Vg1 protein is an axial mesoderm inducer in Xenopus. Cell 74:433-441

4. Asashima M, Nakano $H$, Shimada K, Kinoshita K, Ishii K, Shibai $H$, Ueno N 1990 Mesodermal induction in early amphibian embryos by activin $A$ (enthroid differentiation factor). Roux Arch Dev Biol 198:330-335

5. Smith JC, Price BMJ, van Nimmen K, Huylebroeck D 1990 Identification of a potent Xenopus mesoderminducing factor as a homologue of activin A. Nature 345: 729-731

6. Thomsen G, Woolf T, Whitman M, Sokol S, Vaughan J, Vale W, Melton DA 1990 Activins are expressed early in Xenopus embryogenesis and can induce axial mesoderm and anterior structures. Cell 63:485-493

7. van den Eijnden-van Raaij AJM, van Zoelent EJJ, van Nimmen K, Koster CH, Snoek GT, Durston AJ, Huylebroeck D 1990 Activin-like factor from a Xenopus laevis cell line responsible for mesoderm induction. $\mathrm{Na}$ ture 345:732-734

8. Zhou X, Sasaki H, Lowe L, Hogan BLM, Kuehn MR 1993 Noda/ is a novel TGF- $\beta$-like gene expressed in the mouse node during gastrulation. Nature 361:543-547

9. Basler K, Edlund T, Jessell TM, Yamada T 1993 Control of cell pattern in neural tube: regulation of cell differentiation by dorsalin-1, a novel TGF- $\beta$ family member. Cell 73:687-702

10. Jost A 1947 Recherches sur la differenciation sexuelle de l'embryon de lapin. Arch Anat Microl Morphol Exp 36: 271-315

11. Cate RL, Mattaliano RJ, Hession C, Tizard R, Farber NM, Cheung A, Ninfa EG, Frey AZ, Gash DJ, Chow EP, Fisher RA, Bertonis JM, Torres G, Wallner BP, Ramachandran KL, Ragin RC, Manganaro TF, MacLaughlin DT, Donahoe PK 1986 Isolation of the bovine and human genes for Mullerian inhibiting substance and expression of the human gene in animal cells. Cell 45:685-698

12. Behringer RR, Cate RL, Froelick GJ, Palmiter RD, Brinster RL 1990 Abnormal sexual development in transgenic mice chronically expressing Mullerian inhibiting substance. Nature 345:167-170

13. Wozney JM, Rosen V, Celeste AJ, Mitsock LM, Whitters MJ, Kriz RW, Hewick RM, Wang EA 1988 Novel regulators of bone formation: molecular clones and activities. Science 242:1528-1534

14. Luyten FP, Cunningham NS, Ma S, Muthukumaran N, Hammonds RG, Nevins WB, Wood WI, Reddi AH 1989 Purification and partial amino acid sequence of osteogenin, a protein initiating bone differentiation. J Biol Chem 264:13377-13380

15. Ozkaynak E, Rueger DC, Drier EA, Corbett C, Ridge RJ, Sampath TK, Oppermann H 1990 OP-1 cDNA encodes an osteogenic protein in the TGF- $\beta$ family. EMBO $J$ 7:2085-2093

16. Sampath TK, Coughlin JE, Whetstone RM, Banach D, Corbett C, Ridge RJ, Ozkaynak E, Oppermann H, Rueger DC 1990 Bovine osteogenic protein is composed of dimers of OP-1 and BMP-2a, two members of the transforming growth factor- $\beta$ superfamily. J Biol Chem 265: 13198-13205

17. Kingsley DM, Bland AE, Grubber JM, Marker PC, Russell LB, Copeland NG, Jenkins NA 1992 The mouse short ear skeletal morphogenesis locus is associated with defects in a bone morphogenetic member of the TGF- $\beta$ super- 
18. Storm EE, Huynh TV, Copeland NG, Jenkins NA, Kingsley DM, Lee S-J 1994 Limb alterations in brachypodism mice due to mutations in a new member of the TGF- $\beta$ superfamily. Nature 368:639-643

19. Lin L-FH, Doherty DH, Lile JD, Bektesh S, Collins F 1993 GDNF: a glial cell line-derived neurotrophic factor for midbrain dopaminergic neurons. Science 260:11301132

20. McPherron AC, Lee S-J 1993 GDF-3 and GDF-9: two new members of the transforming growth factor- $\beta$ superfamily containing a novel pattern of cysteines. J Biol Chem 268:3444-3449

21. Giordano G, Barreca A, Minuto F 1992 Growth factors in the ovary. J Endocrinol Invest 15:689-707

22. Hutson J, Ikawa H, Donahoe PK 1981 The ontogeny of Mullerian inhibiting substance in the gonads of the chicken. J Pediatr Surg 16:822-827

23. Vigier B, Picard J-Y, Tran D, Legeai L, Josso N 1984 Production of anti-Mullerian hormone: another homology between Sertoli and granulosa cells. Endocrinology 114: 1315-1320

24. Vigier B, Watrin F, Magre S, Tran D, Josso N 1987 Purified bovine AMH induces a characteristic freemartin effect in fetal rat prospective ovaries exposed to it in vitro. Development 100:43-55

25. Lyons KM, Pelton RW, Hogan BLM 1989 Patterns of expression of murine $\mathrm{Vgr}-1$ and BMP-2a RNA suggest that transforming growth factor- $\beta$-like genes coordinately regulate aspects of embryonic development. Genes Dev 3:1657-1668

26. Keshet E, Lyman SD, Williams DE, Anderson DM, Jenkins NA, Copeland NG, Parada LF 1991 Embryonic RNA expression patterns of the c-kit receptor and its cognate ligand suggest multiple functional roles in mouse development. EMBO J 10:2425-2435

27. Lyons K, Graycar JL, Lee A, Hashmi S, Lindquist PB, Chen EY, Hogan BLM, Derynck R 1989 Vgr-1, a mammalian gene related to Xenopus $\mathrm{Vg}-1$, is a member of the transforming growth factor $\beta$ gene superfamily. Proc Natl Acad Sci USA 86:4554-4558

28. Tsafriri A, Pomerantz SH, Channing CP 1976 Inhibition of oocyte maturation by porcine follicular fluid: partial characterization of the inhibitor. Biol Reprod 14:511-516

29. Sato E, Koide SS 1984 A factor from bovine granulosa cells preventing oocyte maturation. Differentiation 26: $59-62$

30. Garbers DL 1989 Molecular basis of fertilization. Annu Rev Biochem 58:719-742

31. Villanueva-Diaz C, Vadillo-Ortega F, Kably-Ambe A 1990 Evidence that human follicular fluid contains a chemoattractant for spermatozoa. Fertil Steril 54:1180-1182

32. Ralt D, Goldenberg M, Fetterolf $P$, Thompson D, Dor J, Mashiach S, Garbers DL, Eisenbach M 1991 Sperm attraction to a follicular factor(s) correlates with human egg fertilization. Proc Natl Acad Sci USA 88:2840-2844

33. Wilkinson DG, Bailes JA, McMahon AP 1987 Expression of the proto-oncogene int-1 is restricted to specific cells in the developing mouse embryo. Cell 50:79-88

34. Burnette WN 1981 "Western blotting:" electrophoretic transfer of proteins from sodium dodecyl sulfate-polyacrylamide gels to unmodified nitrocellulose and radiographic detection with antibody and radioiodinated protein A. Anal Biochem 112:195-203

35. Lee S-J 1990 Identification of a novel member of the transforming growth factor- $\beta$ superfamily. Mol Endocrinol 4:1034-1040 